University of Nebraska - Lincoln

DigitalCommons@University of Nebraska - Lincoln

Roger Kirby Publications

Research Papers in Physics and Astronomy

April 1997

\title{
Optical and magneto-optical properties of MnPt3 films (abstract)
}

Kurt W. Wierman

Seagate Corporation, Pittsburgh, PA

J. N. Hilfiker

University of Nebraska - Lincoln

Renat F. Sabiryanov

University of Nebraska - Omaha, rsabirianov@mail.unomaha.edu

Sitaram Jaswal

University of Nebraska, sjaswal1@unl.edu

Roger D. Kirby

University of Nebraska-Lincoln, rkirby1@unl.edu

See next page for additional authors

Follow this and additional works at: https://digitalcommons.unl.edu/physics_kirby

Part of the Physics Commons

Wierman, Kurt W.; Hilfiker, J. N.; Sabiryanov, Renat F.; Jaswal, Sitaram; Kirby, Roger D.; and Woollam, John A., "Optical and magneto-optical properties of MnPt3 films (abstract)" (1997). Roger Kirby Publications. 9. https://digitalcommons.unl.edu/physics_kirby/9

This Article is brought to you for free and open access by the Research Papers in Physics and Astronomy at DigitalCommons@University of Nebraska - Lincoln. It has been accepted for inclusion in Roger Kirby Publications by an authorized administrator of DigitalCommons@University of Nebraska - Lincoln. 


\section{Authors}

Kurt W. Wierman, J. N. Hilfiker, Renat F. Sabiryanov, Sitaram Jaswal, Roger D. Kirby, and John A. Woollam 


\section{Optical and magneto-optical properties of $\mathrm{MnPt}_{3}$ films (abstract)}

K. W. Wierman

Behlen Laboratory of Physics, University of Nebraska, Lincoln, Nebraska 68588

J. N. Hilfiker

Department of Electrical Engineering, University of Nebraska, Lincoln, Nebraska 68588

R. F. Sabiryanov, S. S. Jaswal, and R. D. Kirby ${ }^{\text {a) }}$

Behlen Laboratory of Physics, University of Nebraska, Lincoln, Nebraska 68588

J. A. Woollam

Department of Electrical Engineering, University of Nebraska, Lincoln, Nebraska 68588

Optically thick films of $\mathrm{MnPt}_{3}$ were prepared by magnetron sputtering onto quartz substrates. Postdeposition annealing at $850^{\circ} \mathrm{C}$ resulted in highly textured (111) films with the $L 1_{2}\left(\mathrm{Cu}_{3} \mathrm{Au}\right)$ structure. $\mathrm{MnPt}_{3}$ films are ferromagnetic with a Curie temperature of $380{ }^{\circ} \mathrm{C}$, and they show large magneto-optical effects in the visible. ${ }^{1,2}$ These films also show a high degree of long-range order. The diagonal components of the dielectric tensor were determined using variable angle spectroscopic ellipsometry measurements over the spectral range 1.2-2.4 eV. Magneto-optic Kerr rotation and ellipticity measurements were made at near normal incidence over the spectral range $1.4-3.6 \mathrm{eV}$ to determine the off-diagonal components of the $\mathrm{MnPt}_{3}$ dielectric tensor. First-principles electronic structure calculations were carried out for the ordered $\mathrm{MnPt}_{3}$ structure, and from these the components of the dielectric tensor were calculated. We find excellent agreement between the measured and calculated diagonal components, but only fair agreement for the off-diagonal components. (C) 1997 American Institute of Physics. [S0021-8979(97)87008-9]

Research sponsored by the NSF under Grant No. OSR-92355225 and by the Center for Materials Research and Analysis.

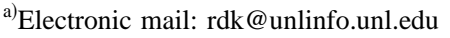

${ }^{1}$ K. W. Wierman and R. D. Kirby, J. Magn. Magn. Mater. 154, 12 (1996).

${ }^{2}$ T. Kato, pH. Kikusawa, S. Iwata, S. Tsunashima, and S. Uchiyama, J. Magn. Magn. Mater. 140-141, 713 (1995). 